\title{
3. Opening and Closing the Land: Land and power in the Idaté highlands
}

\author{
Judith Bovensiepen
}

In 2006, Xanana Gusmão, the then President of Timor-Leste, launched a national program to 'return sharp and pointed materials/weapons' (Tetun: halot meit ho kroat). The aim of the program was to initiate a series of small ceremonies all over the country, in which weapons that had been taken up to fight the Indonesian military would be returned to their proper places (Trindade and Castro 2007:43). Conflicts broke out in Timor-Leste in April 2006 after a dispute within the East Timorese military erupted and turned into a more generalised conflict between different regional factions throughout the country. This internal conflict occurred just four years after Timor-Leste had gained independence following a long and violent period of occupation by Indonesia (1975-99). Gusmão's program was based on the premise that during the resistance struggle against Indonesia, weapons containing ancestral potency had been taken from people's ritual houses and they had not been returned. The failure to restore these weapons to their proper storing places was given as the reason conflicts erupted in the country in 2006. The ceremonies were aimed at returning these weapons to the ritual houses in order to create peace and stability in the country.

In the Laclubar subdistrict in the central highlands, a slightly different interpretation of these events was given, which more or less followed the same line of reasoning. Several of the people in Laclubar maintain that during the Indonesian occupation, the land was opened to fight the occupiers. Conflicts erupted in 2006 because of a failure to hold a ritual to 'close the land' (Idaté: douk larek). The lulik potency of the landscape is considered to be a powerful resource during warfare once it is properly mobilised by human beings who can 'open the land' (Idaté: lo'e larek). Lulik land always needs to be repaid, however, and people argue that conflicts erupted in 2006 because of a failure to do this.

In the Laclubar subdistrict, certain sites in the landscape, particular objects and houses are considered to be potent, or lulik (Idaté and Tetun). Lulik has commonly been translated as 'holy', 'sacred' and 'taboo' (Hull 2002:227). Borrowing directly from Durkheim, David Hicks (2004:25), who carried out research among the Tetun people of south-eastern Timor in the 1960s, maintains that lulik means sacred and that this is opposed to the category for the profane: sau. Similarly, Elizabeth Traube (1986:143), whose research in the 1970s focused on the Mambai people of central Timor, argues that lulik does not refer to an essence but is rather a relational category that 'signifies a relation of distance, 
a boundary between things'. Among Idaté speakers, lulik is used as an adjective, noun and verb and can designate an avoidance relationship, but also refers to a potent source of power, prosperity and danger, usually associated with the land and the ancestors.

This chapter focuses on Idaté narratives about the political significance of lulik land. It investigates how attachment to place is created through this narrative practice and how this in turn reinforces the central significance of the potency with which the ancestral land is invested. This will allow me to explore how people perceive the relationship between humans and their environment by concentrating on the way narratives mediate this relationship. In the first part of the chapter, I introduce the Laclubar subdistrict, its history and spiritual geography, focusing specifically on people's understanding of lulik potency in relation to ancestral activities. Subsequently, I draw out how people's claims to the potency of the land vis-a-vis outsiders are expressed in a narrative that concerns Laclubar's interactions with colonial powers and neighbouring domains. In the final part, I discuss the role of this narrative in the present, how it is used to interpret the current conflict as a failure to 'close the land', and explore how competing political perspectives are reflected in people's conflicting claims to have access to the land's potency.

\section{Overview of Laclubar History and Spiritual Geography}

Laclubar subdistrict is part of the district of Manatuto and is situated in the central mountain range of Timor-Leste, some $130 \mathrm{~km}$ by road from the capital city, Dili. With a population of about 8000 people (NDS 2006:67), the subdistrict is divided into six smaller administrative units or villages called suco, and is one of the most thinly populated areas of Timor-Leste (Arquitectura and GERTiL 2002:81). The language spoken in the region is Idaté, an Austronesian language closely related to the national language, Tetun. ${ }^{1}$ Most of the inhabitants in this region are subsistence farmers and grow a variety of tubers, maize, citrus fruits and coffee, and there are some rice fields in the lowlands. The region is also known for its production of palm wine, which is traded during Sunday markets in Laclubar Town. There are also oil and gas resources in the area around Pualaka. Most hamlets outside Laclubar Town cannot be reached by car, and heavy rainfall frequently leads to some of the hamlets being entirely cut off from the main roads, health stations and markets. Laclubar Centre has a newly built hospital, a large church and several schools.

\footnotetext{
1 Idaté is spoken by approximately 10000 people, mainly in the Laclubar subdistrict. The inhabitants of the area frequently mix Idaté and Tetun, which is why I use both languages in this chapter.
} 
During the Indonesian occupation of East Timor, the inhabitants of the more remote hamlets and villages were forcibly resettled in Laclubar Town, and a large part of the population has returned to their ancestral lands since independence. A certain proportion of the population still lives in West Timor, to where they were voluntarily or forcibly moved during the post-referendum violence in 1999. In other regions of Timor-Leste, the inhabitants of Laclubar are sometimes considered to have been supporters of Indonesian occupation, since the East Timorese Governor during the Indonesian occupation, Abílio Osório Soares, was born in Laclubar. Political affiliation in the area varies widely, however, and in the 1970s there were supporters of all three main parties in Laclubar: Fretilin, UDT and Apodeti. During the internal conflict that broke out in the country in 2006 - which was frequently expressed in terms of a conflict between easterners (Tetun: lorosa'e) and westerners (Tetun: loromonu) - many of Laclubar's inhabitants insisted they were 'neutral' arguing that they were 'the land of the middle' (Tetun: rai klaran).

Laclubar Town is situated in a small valley, surrounded by steep mountains that form around the town centre in the shape of a horseshoe. The landscape is characterised by rugged mountains and fertile stretches of forest interspersed with small springs. Certain conspicuous sites in the landscape, such as springs, stones, rivers, hilltops or holes in the ground, are considered to be potent (lulik) and must be avoided. Two important lulik sites near Laclubar Centre are called Susuk and Orlau. Susuk is a wide hole at the bottom of the mountains surrounding Laclubar Town. Orlau is a spring located in a forested area close to the main road leading to Laclubar Centre, in a lush and fertile area planted with fruit trees and coffee. Susuk and Orlau are two of the most important ritual sites for the inhabitants of Laclubar, because they are considered to be doorways (Idaté: lalamatak) to lulik potency. Rituals to mobilise this potency were carried out at these sites, including the ritual to 'close the land'.

During everyday activities, lulik sites must be avoided because they are considered dangerous, and walking too close to lulik sites is said to risk madness, confusion and death. Lulik is gendered female, even though I found no evidence to suggest that people identified the land with a specific female deity, as described by Hicks (2004:27) for the Tetun people of Caraubalo. Those I encountered during my fieldwork in Laclubar maintained that at lulik places one is likely to encounter land spirits (Idaté: larek-nain), which can appear in the form of pythons, eels or as human beings, such as a beautiful woman or a foreigner (Idaté and Tetun: malae) with white skin and red hair. The Idaté term larek-nain has multiple meanings: it can refer to land spirits who appear at lulik sites. The term also refers, however, to the earliest population of the area and their descendents, who are the 'people of the land' or landowners today (cf. Hicks 2004:30; McWilliam, this volume). Hence, the category of larek-nain is 
frequently merged with ancestors (Idaté luli'ain). There is an ambiguity about the precise nature of the relationship between ancestors, lulik and land spirits. When asked directly, the people I spoke to said these categories are not the same, however, during ritual and everyday interactions with the land, these entities were often conflated. Thus, although they are conceptually separate, they are implicitly treated as transformations of each other and their combined presence in the land makes up its powerful potency.

Lulik is said to precede human ancestors. One of my respondents, named Ghuillermino, expressed this by saying: 'in the past, there was lulik, nothing else.' He went on to explain that before human beings came into existence, there was just potent lulik land in Laclubar. Subsequently, land spirits created human beings and raised animals. Some ancestors grew from the land and others came from stones. The land gave golden objects to people and they built houses for these objects. His narrative absorbs biblical notions of the human genesis by stating that God gave His blessing to this act of creation, but it was the land that created human beings. He concluded that 'everything comes from the land'. In this line of thinking, human beings are extensions of the land; they emerge directly from it. Lulik is thus closely linked to notions of autochthony in that the original inhabitants are said to have emerged from the potent landscape. The autochthonous origins of the original population are expressed in the narratives of different house groups, which recount the origins of the first ancestral siblings travelling through the landscape in order to find an appropriate place to settle. In several cases, the name of the house group refers to the place where the ancestors settled or emerged from the landscape, thus uniting the land, the house and its human members in a single entity. These origin narratives are frequently described through the recitation of place names, which the ancestors visited - a practice that Fox (1997a:8) has called 'topogeny'. The recitation of these narratives creates emplacement (cf. Scott 2007:33), continuously reestablishing attachment to the ancestral environment. The recounting of narratives is therefore an essential part of the way people make place.

Territorial place making, according to Feuchtwang (2004:10), is a way of centring and establishing focal points. People in Laclubar create a sense of centrality through various idioms. Some house groups express this through the common Austronesian botanical metaphor of likening their ancestral origin house to a banyan tree, whose ancestors are the 'trunk' or 'base' (Idaté: uun) and whose descendants are the tips or flowers of the tree (Idaté: hunan) (cf. Reuter 2006:25). The sense of centrality is also expressed through bodily metaphors according to which Laclubar is 'the navel of the land, the liver of the land' (larek usar, larek nau). The west of Timor-Leste represents the tail of the land (Idaté: hiak) and the east the head (Idaté: ulun). The navel land, called Balulin, refers to a hole in the ground, which is situated at the bottom of Mount Maubere near Laclubar Centre. 
This lulik site represents the place where the original ancestors of Laclubar were buried and it is thought to be the entrance to the world of underground spirits. The claim to be the navel of the world is a way of expressing that Laclubar is the origin place of humanity (cf. Therik 2004:69-70), and people at times contend that the first ancestors were actually Adam and Eve (cf. Fox 1983). Thus, by identifying themselves as the centre of the world and the origin place of human history, Laclubar's inhabitants are creating a powerful focal point that anchors them firmly in the landscape.

Claims to centrality are also a way in which precedence (Fox 1997b:91) is established in relation to other incoming groups. The autochthonous inhabitants are the ritual guardians of the land. Hence the land cannot be alienated, or, as Ghuillermino said, 'the land does not want to be sold'. The potency of lulik sites makes them particularly 'hot' and thus dangerous. Claims to centrality are often accompanied by an emphasis on the potency of the land, which is at times expressed through the notion that lulik sites are places where gold is located under the earth. Moreover, as the following narrative illustrates, the land is said to have given golden objects to the original inhabitants, thus bestowing them with entitlement to political leadership.

\section{The Narrative of the Golden Star}

As in many other regions of South-East Asia (Errington 1990:47), in Laclubar, there is a distinction between ritual and political power. These two kinds of power are closely intertwined and essentially interdependent. Lulik potency may be a source of ruling power (Idaté and Tetun: ukun). This is illustrated through an important narrative that recounts the independence of Laclubar from the neighbouring domain, Samoro. The narrative concerns the story of an ancestor of Laclubar called Dom Geraldo who managed to gain independence from the neighbouring domain or 'kingdom' (Portuguese: reino), Samoro, through the help of lulik land. It is one of the most frequently told stories in this region and is part of a longer narrative that concerns the origins and journeys of the first ancestors. People were keen for me to record this account and it was told on many occasions during rituals and other public events. Nearly everyone in the region knows and recognises this story and people take great pleasure in telling it and listening to the narrative. There are several different versions of this narrative. Every narrator told the story in a slightly different way, occasionally changing the names of the main actors, adding or leaving out details or making different interpretations of the meaning of the story for the 
present-day situation. In this version, I summarise the most important elements that recur in most of the accounts in a way I believe most of the narrators would accept. $^{2}$

In the past, Laclubar had to listen to orders from the reino of Samoro. Then, good fortune was brought to one of the ancestors: the lulik land Susuk 'gave' good fortune to an ancestor called Dom Geraldo. During that time, palm wine was stolen from the field of Dom Geraldo, whose 'pagan name' is Kei Tu. This happened over and over again. ${ }^{3}$ Dom Geraldo set out to catch the thief. [In some versions of the story, Dom Geraldo sends someone else to the field, called Bita Loin.] During the night, he sat under the palm trees and waited. But he became very tired and fell asleep. The next morning he woke up and saw that the palm wine was gone. The same event took place the next day and then again the following day. But Dom Geraldo never managed to stay awake to catch the thief who was stealing his palm wine.

So one night, he cut open his finger and squeezed lemon juice into the wound. He did this all night and, because of the pain, he did not fall asleep. Suddenly he heard a noise. He jumped up and said, 'Oyye! Who is it? Who has been stealing my palm wine?' Once he uttered the words, a golden star appeared above him. The star said to the ancestor: 'I have been stealing your palm wine. What do you want from me to reimburse you for my theft?' Dom Geraldo answered, 'I don't want anything. I don't want any wealth or treasures. The only thing I want is independence [or self-rule; Tetun: ukun-rasik-an].' And that is what happened. The lulik land Susuk, where Dom Geraldo's palm trees were planted, 'gave good fortune' and independence to Laclubar's ancestor. The land bestowed the title 'Dom' to Geraldo 'Kei Tu', hence making him a local ruler or liurai.

This account is often followed by another short story, which is thought to be directly related to this earlier account and gives another perspective of the relationship between Laclubar and Samoro.

The ruler of Samoro, Dom Felis, was not very happy about Laclubar's efforts to become independent. [The name of the liurai of Samoro differs in some versions.] Hence Dom Geraldo and Dom Felis were summoned to appear in front of the Governor in Dili in order to resolve the dispute

2 My own explanations are included in square brackets.

3 In Timor-Leste, palm wine (Idaté: nau buti) is often produced far away from home directly in the field. A bamboo container is attached to the palm tree, while the branches are beaten for several days with the wine slowly dripping into the bamboo container. Some people distil the product and make a stronger liquor (Idaté: nau arak). 
[the Governor is referred to as the Governador or the Administrador]. It took Dom Felis three days to get to Dili, as he rode on horseback. But Dom Geraldo asked the lulik land for advice: 'Who do I ride?' he said. The lulik land told him to 'ride on brother wind' [Tetun: sai kuda mau anin]. He did this by entering a hole in the ground and by reappearing straight away in Dili at the Governor's house. When Dom Geraldo arrived, the Governor told him to wash and put on some clothes. Dom Geraldo put on the Governor's uniform and his hat and sat outside on the porch, waiting for Dom Felis. When Dom Felis finally arrived, he did not recognise Dom Geraldo, so he greeted him by saying 'Bondia, Senhor Governador.' [In some versions of the story, he greets him by saying 'Bondia, liurai.'] The Governor heard this and said to Dom Felis: 'You greeted Dom Geraldo. Now you shall both have a flag each and a drum each!' [The drum and the flag are symbols of rule.] This meant Laclubar had gained self-determination. Henceforth Dom Geraldo ruled over Laclubar and Dom Felis ruled over Samoro. ${ }^{4}$

The most important aspect of this story is indisputedly the fact that the lulik land 'gave' good fortune and independence to Laclubar. In the story, the golden star embodies the lulik land. People narrating the story use the two expressions interchangeably: 'the golden star brought good fortune to Dom Geraldo' or 'the [lulik] land gave good fortune to Dom Geraldo'. Through the intervention of the lulik land alone, the inhabitants of Laclubar obtained self-determination. The fact that Dom Geraldo was mistakenly addressed as liurai by the ruler of Samoro was due to the fact that the land had 'given good fortune' to Dom Geraldo.

According to this narrative, lulik legitimises the political position and authority of ancestral rulers and the current political order, because the descendants of Dom Geraldo are considered to be the righteous heirs of the position of the traditional ruler (liurai) today. People who tell this story claim that it is proof of the power and strength of the lulik land because the lulik land Susuk gave political independence to Dom Geraldo and by extension to the people of Laclubar. By continuously recounting this story at gatherings, rituals or public events, the strength and importance of the lulik are established and reinforced. Hence one might say that lulik land is partly so strong and powerful because of the narratives that are told about it. Lulik land and the narratives about it are mutually constitutive.

Moreover, the narrative illustrates several points I made about the nature of lulik potency earlier, such as the fact that it is considered to have agency of its own, by 'giving good fortune' and advice to Dom Geraldo. The idea of Dom Geraldo 'riding the wind' to Dili by climbing into a hole in the ground reinforces

4 Some people today refer to Laclubar as the 'little Samoro' (in Tetun: Samoro kiik). 
my suggestion that lulik is associated with the underground. Moreover, some narrators claim that in return for giving independence to Laclubar, the lulik land took away Dom Geraldo's wife, because she died shortly after independence. They say the land 'wanted' his wife; she was the sacrifice for independence. Agency and motivation are attributed to lulik, which is potentially dangerous. While interactions with lulik land might be productive, they are also dangerous; for one human being to channel the potency of the underground, another human being must join it.

In Laclubar, several different individuals claim that they or their house group are the rightful descendants of Dom Geraldo in the present day and thus have the right to political power as the local ruler or liurai. The controversy over these claims is related to the content of the narrative. Some argue that Bita Loin, who in some versions of the narrative encountered the golden star instead of Dom Geraldo, is actually the legitimate ruler, but that he was forced to pass the sceptre - that is, political rule - to the house of Dom Geraldo. Opposed to this is the claim that the descendants of Dom Geraldo are the legitimate rulers and that Bita Loin was merely Dom Geraldo's servant. Moreover, there is controversy about which house groups descend from Bita Loin and from Dom Geraldo, because the houses split into different sub-houses and several people claim descent and the right to be in power. None of this, however, is expressed directly, but can be deduced from the way the story of the golden star is told and interpreted.

Narratives about ancestral interactions with the land and particular lulik sites establish long-lasting attachment between house groups and certain sites in the landscape. Attachment to land and claims to authority deduced from this are created discursively by emphasising the potent connections with the landscape. Despite the emphasis on these autochthonous connections, the narrative of the golden star also contains a number of references to the Portuguese interference in this relationship.

\section{Colonial Evaluations of the Land}

The people who recounted the narrative of the golden star tend to represent this story as a victory of the people of Laclubar over their neighbours in Samoro. They use the story to assert the fact that the people in Laclubar are independent and do not 'listen to orders from Samoro'. Interestingly though, the narrators rarely make explicit references to the Portuguese when telling this story. This is surprising considering the fact that there are several implicit references to the Portuguese in the narrative: the Portuguese title 'dom', the flag, Portuguese 
names and, most importantly, the 'Governador' in Dili. When asked specifically, most narrators concede that the Governor was probably a 'foreigner' (malae), but this is rarely mentioned when the story is recounted.

Considering that in the narrative Dom Geraldo and Dom Felis seek advice from the Governor in Dili, who decides that the two domains should be ruled separately, it is likely that this narrative refers to a change in the administrative boundaries undertaken by the Portuguese colonial government at the time. According to the Portuguese records, Laclubar was recognised as an independent domain only in 1868, by Governor Afonso de Castro (Corréa 1934:277). In 1896, Governor Celestino da Silva mentions Laclubar as one of those domains that was 'not yet subjugated' (Pélissier 1996:137), and in 1898 a military post was established in Laclubar (Pélissier 1996:180). It is possible that the story of the golden star refers to these events, which led to the recognition of Laclubar as an independent domain by the Portuguese. Moreover, when the military post was established, the Portuguese also appointed a local ruler of Laclubar by granting him the title of 'dom'. It is interesting to note that although the establishment of indirect rule in Laclubar probably meant a loss of independence through subjugation to an external colonial administration, it is recounted in the local narrative as a story of victory. The independence of Laclubar as an administrative unit that is separate from its neighbours is presented as a product of local circumstances, not as the outcome of external interference. What is clearly a colonial division of the region is recounted as the intervention of lulik land. The narrative thus represents a mythical justification of social and political relations via people's connection with the land.

Another reason for the increasing interest of the Portuguese in Laclubar at the end of the nineteenth century was that petroleum was discovered in the area (Pélissier 1996:241). There are reports from the 1890s onwards about German, British and Australian companies inspecting the area around Pualaca (near Laclubar) for petroleum deposits, and a British company established a more permanent presence by 1910 (Pélissier 1996: 118, 241, 244). When I carried out fieldwork, several people in Laclubar expressed fears that foreigners could come to the region to steal their gold. This concern could reflect an historical worry that foreigners might steal Laclubar's natural resources. Gold stands for the wealth of the natural environment, but also for lulik, as in the case of the golden star where the lulik land, in the shape of a golden star, gave political leadership to Dom Geraldo.

Although in the narrative the foreign governor agrees to Laclubar's independence, the real source of independence and political power is the lulik land. The story diverts authority away from the external colonial institution and projects it onto a local source. So on the one hand, people localise power by projecting it onto the lulik land. On the other hand, power is transferred from the realm of human 
agency onto the realm of subterranean potency. For the people of the Laclubar region, land is a vital resource of wealth and political power that can be gained through its lulik potency. There is, however, strong competition among the claimants for access to lulik sites and by extension to political leadership and authority. By recounting narratives of the potency of the land, people reassert their claims to political influence in the present. Another important connection to the land is its perceived capacity to protect local inhabitants from outsiders.

\section{Raising Troops from the Ground}

In the most commonly told version of the narrative about Dom Geraldo's encounter with the golden star, there is no mention of any fighting or war between Samoro and Laclubar. Nonetheless, a small group of narrators, belonging to the same origin house, recounted a particular addition to the narrative of Dom Geraldo that qualifies the case narrative.

The people of Laclubar were obliged to deliver cotton and wax for candles to Samoro [a form of tribute]. As a sign of their protest, they decided to deliver only very small and poor-quality candles to Samoro. The liurai of Samoro, Dom Felis, was furious about this. So he gathered his best warriors, assembled troops from the neighbouring domains Same, Alas and Barique, and marched towards Laclubar.

When the people of Laclubar heard that the warriors of the three neighbouring domains were approaching, they were scared. So the elders and ritual specialists gathered to ask the lulik land for help. They killed an animal to 'feed' the land and uttered words of ritual speech [Idaté: sede]. When the enemy troops were advancing, suddenly an army of spirits rose from the lulik land around Mount Maubere. The spirits were wearing weapons and they were everywhere. Their fighting screams echoed through the mountains and valleys. To the approaching troops, it looked as if Laclubar was swarming with people and warriors. But in reality, Laclubar was empty. There were no human beings around. Laclubar's inhabitants themselves could not see anyone. But to the troops from Samoro it looked as if an enormous army was waiting for them, prepared to fight. Struck by fear, Samoro's warriors fled. This is how Laclubar won the war over Samoro.

According to this story, Laclubar was saved from being destroyed by its neighbouring domains by raising spirit troops from the ground to frighten them. This kind of protection is referred to as 'opening the land'. The narrators of this story emphasise that just three elders managed to raise a whole army by carrying out a ritual at the lulik sites Susuk and Orlau. The spirit troops who 
were raised are the spirits guardians of Mount Maubere. They are the larek na' in or 'land spirits' that reside below the earth. It is for this reason that people refer to Mount Maubere as 'the warrior' (Idaté and Tetun: asuwa'in).

Narratives of this kind inform and set the context for accounts of more recent events. In 1999, after the referendum that led to East Timor's independence, East Timorese militias and Indonesian troops approached Laclubar. People say that when the Indonesians were coming up the road from Manatuto towards Laclubar they suddenly heard loud screams echoing through Laclubar. The town and surrounding mountains were filled with armed spirit troops. Thinking that members of Falintil - the East Timorese guerrillas - had come out from the forest to fight them, the Indonesians fled in panic. Yet, to the local inhabitants of Laclubar, the town looked empty. Again, it was the spirit troops from Mount Maubere who had saved them.

In 1999, Indonesian troops and local militias did enter Laclubar, destroying and burning parts of the town, and killing a number of people associated with the resistance. This fact seems of little relevance to those telling the story about the underground army, who insist that things would have been much worse otherwise. The main purpose of the account is not to explain why Laclubar was spared or not, but to stress the superiority of the potency of the land visa-vis external forces (cf. Traube 1986:55). The narrative inverts the historical and political relations of power. Similar to the threat posed by the Portuguese colonial government or the neighbouring domain Samoro, faced by an external intruder, the people of Laclubar say they can rely on its autochthonous potency to protect them. Faced by a dis-empowering situation, re-empowerment has to come from an internal other- the potent lulik land.

This is just one example of how narratives of the past are used to interpret what is happening in the present, emphasising the continuing power of lulik potency in people's daily lives. References to lulik land were also made in relation to the internal conflict in Timor-Leste from 2006 onwards, as I illustrated in the introduction. The program launched by Xanana Gusmão to return weapons to the ritual houses is based on the same line of reasoning as the idea that lulik must be returned to the land by 'closing' it. A closing ritual was held at the lulik site Susuk in order to close the land, because people argued that the reason for the conflict in 2006 was a failure to 'thank' the land for its help during the Indonesian occupation. By making an animal sacrifice to the land, harmful forces could be returned to the ground. Hence the relationship with the lulik land is a reciprocal one. And recent conflicts are seen as a failure of the inhabitants of this region to maintain their reciprocal obligations with it (cf. Traube 2007).

There are, however, different opinions as to which elders and political factions in the region were able to open or close the land. Many people thought the 
person who carried out the ritual as part of the national program did not actually possess the knowledge to close the land. Some claimed that the reason for this was that he was not a direct descendant of Dom Geraldo. Yet others were of the opinion that he had lived far away from Laclubar for too long and hence was not capable of carrying out the ritual correctly. People in Laclubar agree that land can be 'opened' to fight wars and has to be 'closed' in order to re-establish peace, but the narratives about lulik land also reflect competing claims to power and leadership.

Lulik land is considered to be invaluable for the protection of the local inhabitants. Nonetheless, there is competition over the access to lulik land. Several different factions in Laclubar claim that only they know how to open or close lulik land. This conflict is never expressed openly, but only through the way people interact with these sites during rituals and through the narratives they tell about the land. In order to continuously reaffirm one's connection with the land, in the face of intense competition, it is necessary to live close to the land to reassert one's own narrative account.

\section{Conclusion}

For the people of the Laclubar subdistrict, the inhabited environment is intersected with an invisible realm of lulik potency, ancestors and land spirits. This realm is a source of fertility, wealth and power, but it can also pose a threat to human beings when the reciprocal obligations towards the land are neglected. The potency of the land may be appropriated for protection during war by 'opening the land' and raising spirit troops from the ground. Once the land has helped its inhabitants, however, animal sacrifices need to be made to the land in order to 'close' it, thus establishing long-term peace and stability.

Narratives mediate between people and the land in three significant ways. First, they are practices through which people create attachment to the ancestral landscape. Second, they are a way in which claims to political leadership are asserted. Through oral narratives that create a connection between a house group and an important ancestor (Dom Geraldo), whose political position was established through a gift from the landscape, lulik potency is transformed into a source of ruling power ( $u k u n$ ). Competing accounts reveal rivalry and lingering conflicts about the legitimacy of the local ruler (liurai) of Laclubar in the present day. This competition is expressed not only in claims about the descendants of Dom Geraldo, but also in rival claims about who is entitled and knowledgeable to close or open the land.

A third way in which oral narratives mediate between people and place is that they allow people to invert and reframe historical experiences. The accounts 
I discuss in this chapter give a local account of colonial and neo-colonial interventions by Portuguese and Indonesian powers, and the more recent internal conflict in 2006. In these narratives, people make sense of external decisions and changes in government that are beyond their immediate control. As a repository of autochthonous potency, the ancestral land localises external influences. In the narratives discussed here, dis-empowering situations are inverted by attributing historical agency to lulik land, which ultimately is considered to determine the course of events.

\section{Acknowledgments}

This chapter is based on fieldwork in Timor-Leste (2005-07) made possible by financial support from the Wenner-Gren Foundation for Anthropological Research, the Economics and Social Research Council (ESRC), and the German National Academic Foundation (Studienstiftung des deutschen Volkes). I would like to thank Andrew McWilliam, Elizabeth Traube, James Fox, Hercus do Santo and Lisa Palmer for their helpful comments. I would also like to thank the people of the Laclubar subdistrict for their valuable assistance during my fieldwork.

\section{References}

Arquitectura, F. d. and GERTiL 2002, Atlas de Timor Leste, GERTiL, Grupo de Estudos de Reconstrução de Timor Leste, Faculdade de Arquitectura Universidade Técnica de Lisboa, Lidel-edições técnicas, Ida, Lisboa, Porto, Coimbra.

Corréa, P. A. 1934, Gentio de Timor, Edicão do Autor, Lisboa.

Errington, S. 1990, 'Recasting sex, gender, and power: a theoretical and regional overview', in S. Errington and J. M. Atkinson (eds), Power and Difference: Gender in island Southeast Asia, Stanford University Press, Stanford, Calif., pp. 1-58.

Feuchtwang, S. 2004, 'Theorising place', in S. Feuchtwang (ed.), Making Place: State projects, globalisation and local responses in China, UCL Press, London and Portland, Ore., pp. 3-30.

Fox, J. J. 1983, 'Adam and Eve on the island of Roti: a conflation of oral and written traditions', Indonesia, vol. 36, pp. 15-23.

Fox, J. J. 1997a, 'Place and landscape in comparative Austronesian perspective', in Poetic Power of Place: Comparative perspectives on Austronesian ideas of 
locality, Department of Anthropology, Published in association with the Comparative Austronesian Project, Research School of Pacific and Asian Studies, The Australian National University, Canberra, pp. 1-21.

Fox, J. J. 1997b, Poetic Power of Place: Comparative perspectives on Austronesian ideas of locality, Department of Anthropology, Published in association with the Comparative Austronesian Project, Research School of Pacific and Asian Studies, The Australian National University, Canberra.

Hicks, D. 2004, Tetum Ghosts \& Kin: Fertility and gender in East Timor, [Second edn], Waveland, Long Grove, Ill.

Hull, G. 2002, Standard Tetum-English Dictionary, [Third edn], Sebastiao Aparicio da Silva Project, in Association with Instituto Nacional de Linguistica, Timor-Leste, Winston Hills, NSW.

National Directorate of Statistics (NDS) 2006, Timor-Leste Census of Population and Housing 2004, National Directorate of Statistics, United Nations Population Fund, Dili.

Pélissier, R. 1996, Timor en guerre: le crocodile et les Portugais, 1847-1913, R. Pélissier, Orgeval, France.

Reuter, T. 2006, 'Land and territory in the Austronesian world', in T. Reuter (ed.), Sharing the Earth, Dividing the Land: Land and Territory in the Austronesian world, ANU E Press, Canberra, pp. 11-38.

Scott, M. W. 2007, The Severed Snake: Matrilineages, making place, and a Melanesian Christianity in southeast Solomon Islands, Carolina Academic Press, Durham, NC.

Therik, T. 2004, Wehali: The female land-traditions of a Timorese ritual centre, Department of Anthropology, Research School of Pacific and Asian Studies, The Australian National University in association with Pandanus Books, Canberra.

Traube, E. 1986, Cosmology and Social Life: Ritual exchange among the Mambai of East Timor, University of Chicago Press, Chicago.

Traube, E. 2007, 'Unpaid wages: local narratives and the imagination of the nation', Asia Pacific Journal of Anthropology, vol. 8, no. 1, pp. 9-25.

Trindade, J. J. and Castro, B. 2007, Rethinking Timorese Identity as a Peacebuilding Strategy: The Lorosa'e-Loromonu conflict from a traditional perspective, European Union Rapid Reaction Mechanism Programme, Technical Assistance to the National Dialogue Process in Timor-Leste, Funded by the European Union, Implemented by Deutsche Gesellschaft für Technische Zusammenarbeit, Dili. 